\title{
U-PB ZIRCON DATA AND AGES FOR BEDROCK SAMPLES FROMTHE RICHARDSON MINING DISTRICT, BIG DELTA QUADRANGLE, ALASKA
}

Evan Twelker and Paul O`Sullivan

Raw Data File 2020-14

This report has not been reviewed for technical content or for conformity to the editorial standards of DGGS.

2020

STATE OF ALASKA

DEPARTMENT OF NATURAL RESOURCES

DIVISION OF GEOLOGICAL \& GEOPHYSICAL SURVEYS
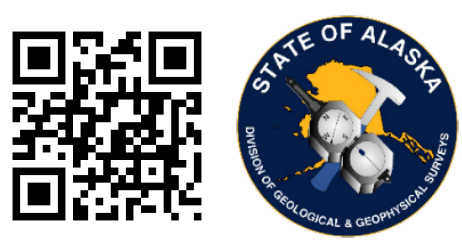
STATE OF ALASKA

Mike Dunleavy, Governor

DEPARTMENT OF NATURAL RESOURCES

Corri A. Feige, Commissioner

\title{
DIVISION OF GEOLOGICAL \& GEOPHYSICAL SURVEYS
}

Steve Masterman, State Geologist \& Director

Publications produced by the Division of Geological \& Geophysical Surveys are available to download from the DGGS website (dggs.alaska.gov). Publications on hard-copy or digital media can be examined or purchased in the Fairbanks office:

\author{
Alaska Division of Geological \& Geophysical Surveys (DGGS) \\ 3354 College Road | Fairbanks, Alaska 99709-3707 \\ Phone: 907.451 .5010 | Fax 907.451.5050 \\ dggspubs@alaska.gov $\mid$ dggs.alaska.gov
}

DGGS publications are also available at:

Alaska State Library, Historical

Collections \& Talking Book Center

395 Whittier Street

Juneau, Alaska 99801

Alaska Resource Library and

Information Services (ARLIS)

3150 C Street, Suite 100

Anchorage, Alaska 99503

\section{Suggested citation:}

Twelker, Evan, and O'Sullivan, Paul, 2020, U-Pb zircon data and ages for bedrock samples from the Richardson mining district, Big Delta Quadrangle, Alaska: Alaska Division of Geological \& Geophysical Surveys Raw Data File 2020-14, 16 p.

https://doi.org/10.14509/30555
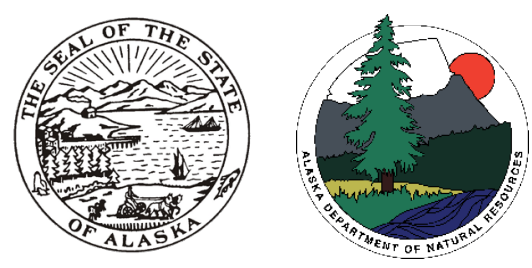


\title{
U-PB ZIRCON DATA AND AGES FOR BEDROCK SAMPLES FROMTHE RICHARDSON MINING DISTRICT, BIG DELTA QUADRANGLE, ALASKA
}

\author{
Evan Twelker and Paul O Sullivan
}

\section{INTRODUCTION}

During the 2017 and 2018 field seasons, geologists from the Alaska Division of Geological \& Geophysical Surveys (DGGS) conducted geologic mapping and sampling in the Richardson mining district southeast of Fairbanks, including parts of the Big Delta B-4, B-5, B-6, and C-6 quadrangles (fig. 1). The project area has produced approximately 122,000 ounces of gold (Singh and others, 2017), mostly from placer mines, and includes the Uncle Sam, Montecristo, Richardson, Tower, and Hilltop lode gold exploration properties. The goal of DGGS's work in this area is to conduct a mineral-resource assessment and to build an improved understanding of the area's geology and controls on gold mineralization to facilitate industry exploration targeting.

Uranium-lead $(\mathrm{U}-\mathrm{Pb})$ zircon geochronology results presented in this report show that similarly textured quartz-feldspar porphyry intrusions in the project area were generated by both Paleocene (56.8 $\pm 0.9 \mathrm{Ma}$; 18WCW149) and middle Cretaceous (92.0 $\pm 0.7 \mathrm{Ma}$; 18AW002, known as the Democrat Dike) magmatic episodes. The ages of medium-grained plutonic rocks at Birch Lake (92.4 $\pm 0.6 \mathrm{Ma} ; 18 \mathrm{ET} 587)$ and Gold Run $(93.7 \pm 0.7 \mathrm{Ma}$; 18ET580) lie within error of the age of the hypabyssal Democrat Dike, indicating that the present-day depth of exposure juxtaposes rocks that were buried at widely different crustal depths during the middle Cretaceous. Phaneritic granodiorite near the Democrat prospect yielded a zircon age of $110.7 \pm 1.3$ $\mathrm{Ma}$ (18RN565), extending the magmatic history of the prospect into the Early Cretaceous. Amphibolite-facies augen orthogneiss yielded a Late Devonian zircon age of $364.5 \pm 6.0 \mathrm{Ma}$ (18ET040), consistent with similar rocks in the Lake George assemblage (Dusel-Bacon and others, 2006). Detrital zircons analyzed from siliciclastic schist along the Richardson Highway (18AW021) contain prominent age populations at 1.8 and $2.6 \mathrm{Ga}$, consistent with a Laurentian cratonic source and consistent with other results from parautochthonous North America (Dusel-Bacon and others, 2017). Pelitic schist from the Hilltop prospect (18TJN372) yielded a relatively small number $(\mathrm{n}=32)$ of zircon grains that define small age populations between ca. 1.7 and $1.5 \mathrm{Ga}$.

The analytical data tables associated with this report are available in digital format as comma-separated value (CSV) files. Additional details about the organization of information are noted in the accompanying metadata file. All files can be downloaded from the DGGS website (http://doi.org/10.14509/30555).

Samples collected during this project will be stored at DGGS for the duration of the project and will be available for public viewing upon request. Once the project concludes, the samples and pulps will be stored at the Alaska Geologic Materials Center in Anchorage. 


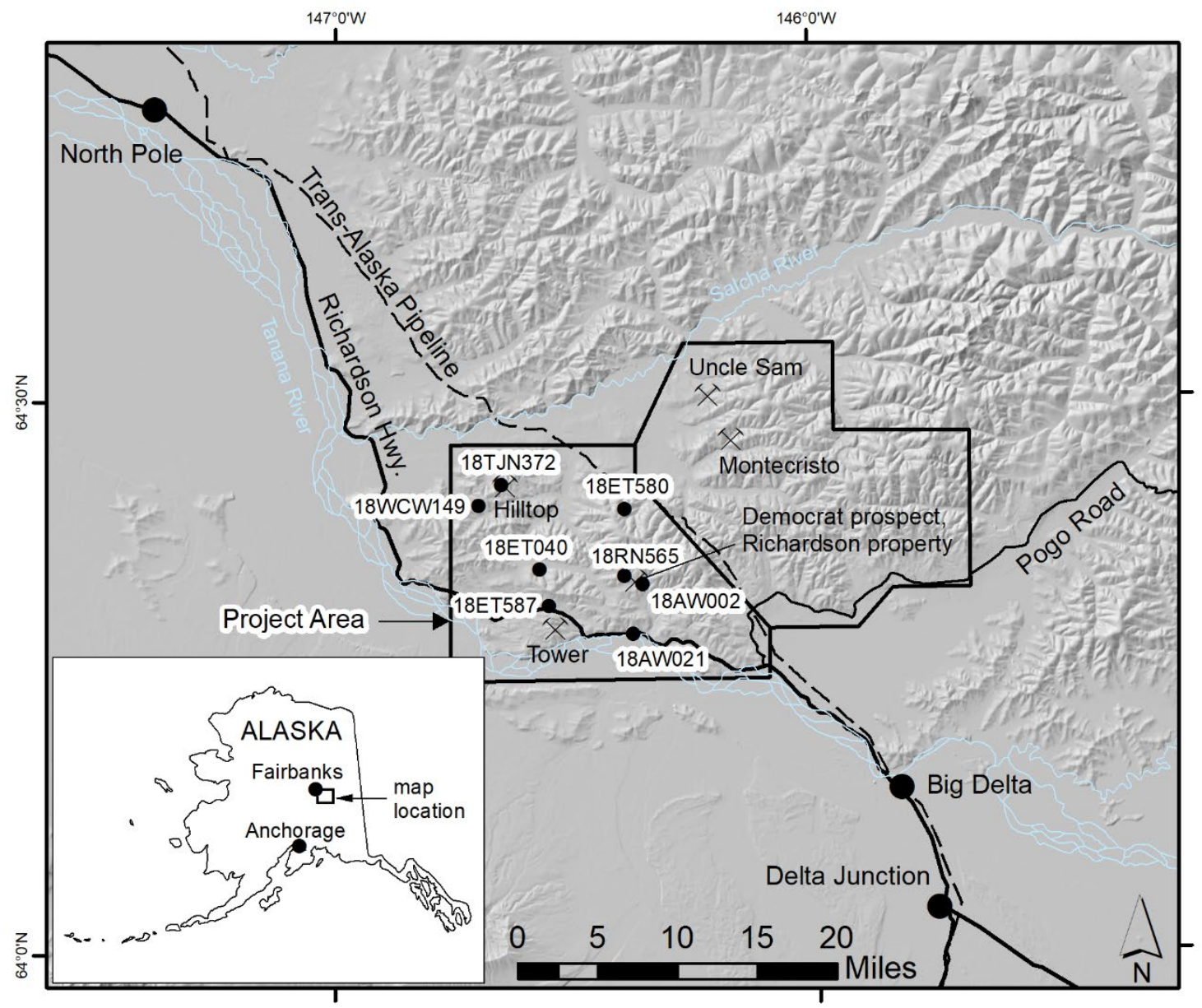

Figure 1. Map showing the location of samples in this report, the DGGS Richardson Project area, and selected gold exploration properties.

\section{ANALYTICALMETHODS}

Zircon grains were extracted at the GeoSep Services laboratory following the detailed description of Donelick and others (2005). Each sample was crushed using a jaw crusher to $<5 \mathrm{~mm}$, the crushate was sieved using 300-micron nylon mesh, the $<300$-micron fraction was washed with tap water and air-dried at room temperature, and zircon was isolated using standard gravimetric and magnetic mineral separation techniques.

Zircon grains were mounted in epoxide resin and polished to a fine finish using 0.3-micron alumina slurry. Zircon grain mounts were stirred vigorously in reagent grade 5.5 molar nitric acid for 20 seconds at $21^{\circ} \mathrm{C}$ and rinsed with distilled water to remove any common lead contamination. Grains, and the locations for laser spots on these grains, were selected for analysis from all sizes and morphologies present using transmitted light with an optical microscope at a magnification of 2000x. This approach is preferred over the use of cathodoluminescence (CL) 2-D imaging as it allows the recognition and characterization of features 
below the surface of individual grains, including the presence of inclusions and the orientation of cracks, which may result in spurious isotopic counts. Furthermore, because of the relatively small grain-sizes present in some analyzed samples, CL imaging would not have contributed useful information on zoning within grains as the location on each grain for analysis was constrained by whether or not the grain was simply large enough to allow a spot analysis.

Data were collected for the following isotopic masses: ${ }^{202} \mathrm{Hg},{ }^{204} \mathrm{Hg}+{ }^{204} \mathrm{~Pb},{ }^{206} \mathrm{~Pb},{ }^{207} \mathrm{~Pb},{ }^{208} \mathrm{~Pb},{ }^{232} \mathrm{Th}$, ${ }^{235} \mathrm{U}$, and ${ }^{238} \mathrm{U}$ ( 250 data scans over 30 seconds) followed by ${ }^{28} \mathrm{Si}$ and ${ }^{91} \mathrm{Zr}$ ( 5 data scans over 4 seconds). The instruments used were a New Wave YAG 213-nm laser ablation (LA) system in line with a Finnigan Element2 magnetic sector, inductively coupled plasma mass spectrometer (ICP-MS) at the Washington State University Geoanalytical Laboratory in Pullman, Washington (Chang and others, 2006). All analyses were performed using a 20-micron spot. Following approximately 6 seconds of background data collection, laser ablation commenced and data were collected for the ablated material. Ablated material was transported to the plasma line using He; Ar was the plasma gas.

Zircon standards for which independently accepted ages are published were designated as primary, secondary, and tertiary for purposes of $\mathrm{U}-\mathrm{Pb}$ age calibration (see table 1 ). Two primary and two secondary standard spots were analyzed prior to and following each group of $~ 25-30$ tertiary standards and/or unknown sample spots. Five spots of each tertiary standard were analyzed near the beginning and again near the end of the session.

Table 1. Zircon standards used during the analysis.

\begin{tabular}{|l|l|l|l|}
\hline Standard & Standard & U-Pb age $(\mathbf{\pm 2} \sigma)$ & Reference \\
\hline FC & Duluth complex & $1099.0 \pm 0.6 \mathrm{Ma}$ & Paces and Miller, 1993 \\
\hline F5 & Duluth complex & $\begin{array}{l}1099.0 \pm 0.6 \mathrm{Ma} \\
\text { (assumed equal to FC-1) }\end{array}$ & Paces and Miller, 1993 \\
\hline IF & Fish Canyon Tuff & $28.201 \pm 0.012 \mathrm{Ma}$ & $\begin{array}{l}\text { Kuiper and others, 2008; } \\
\text { Lanphere and Baadsgaard, 2001 }\end{array}$ \\
\hline MD & Mount Dromedary & $99.12 \pm 0.14 \mathrm{Ma}$ & Renne and others, 1998 \\
\hline PX & Peixe & $563.5 \pm 1.6 \mathrm{Ma}$ & Gehrels and others, 2008 \\
\hline R3 & Braintree complex & $418.9 \pm 0.4 \mathrm{Ma}$ & Black and others, 2004 \\
\hline T2 & $\begin{array}{l}\text { Temora 2, Middledale } \\
\text { gabbroic diorite }\end{array}$ & $416.78 \pm 0.33 \mathrm{Ma}$ & Black and others, 2004 \\
\hline TR & Tardree Rhyolite & $61.23 \pm 0.11 \mathrm{Ma}$ & Dave Chew, personal communication \\
\hline
\end{tabular}

Data Modeling - Previous LA-ICP-MS studies of U-Pb zircon dating deployed the so-called intercept method which assumes that isotopic ratios vary linearly with scan number due solely to linearly varying isotopic fractionation (Chang and others, 2006; Gehrels and others, 2008). For the intercept method, a line is 
fitted to background-corrected isotopic ratio (that is, ${ }^{206} \mathrm{~Pb} /{ }^{238} \mathrm{U}$ ) versus data-scan number and the intercept of the fitted line (corresponding to data scan number $=0$ ) is used as the isotopic ratio for age calculation, and the error on the intercept is used for age error calculation. For this study, individual isotopes were modeled by fitting a sum of 10 Gaussian equations to the raw signal data (not background corrected) using chi-squared minimization. Two fitting passes were performed: After the first pass, all raw-signal values greater than two standard deviations away from the sum of fitted Gaussians were designated as outliers; the second pass fit the sum of Gaussians to the data excluding the outliers. The advantage of the present approach is that it avoids the assumption of linearly varying isotopic ratio with scan number, an assumption easily violated for zircons that may contain useful information (for example, a zircon for which the ablation pit variably penetrates two zones having different $\mathrm{U}-\mathrm{Pb}$ ages).

Measured background values for each isotope at each LA-ICP-MS spot were calculated as follows: A) the final background scan was assigned as the scan closest to the global minima ${ }^{232} \mathrm{Th}$ and ${ }^{238} \mathrm{U}$ values; if no such global minima were found, the analysis was deemed a failure; B) a line was fitted to the background values, outliers identified, and a line again fitted to the data excluding the outliers; C) for a fitted line exhibiting a negative slope (indicative of a decaying background), the value of the line at the last background scan was assigned as the background value; for a fitted line exhibiting a zero or positive slope, the mean value of the data excluding the outliers was assigned as the background value; and, D) the error of the background value was set equal to the standard deviation of the all background values (excluding outliers) about their fitted line (negative slope) or mean (zero or positive slope).

Session-wide fitted background values for each isotope were determined using all zircon standards and applied to all spots in the session. These steps were taken for each isotope: A) measured background value versus spot number in the session was fitted to a $3^{\text {rd }}$-order polynomial, outliers identified, and the fitting repeated excluding the outliers; and, B) fitted background at each session spot was calculated using the $3^{\text {rd }}$ order polynomial. Session-wide fitted background error was set equal to the standard deviation of the measured background values (excluding outliers) about their respective fitted $3^{\text {rd }}$-order polynomial. For any spot (standard or unknown) where the measured background value exceeded the session-wide fitted value by more than $2 \sigma$, the background error was set equal to $1 \sigma$ plus one half of the amount by which the measured background value exceeded the session-wide fitted value by $2 \sigma$.

The sum of fitted Gaussians was used here primarily to identify outlier data and characterize signal noise. After the second fitting pass, the standard deviation of the non-outlier data about their respective sum of fitted Gaussians was taken as the absolute signal error for each data scan. When $\mathrm{N}$ data scans contribute to a single isotopic signal value used for age calculation (only concordant scans when the number of concordant data scans is greater than zero; all data scans for common $\mathrm{Pb}$-correction based on isotopic sums), the error of the single isotopic signal value was set equal to the product of $\mathrm{A}) \mathrm{N}^{1 / 2}$ and $\mathrm{B}$ ) the absolute signal error for each data scan.

$\mathbf{P b} /$ U Fractionation Factor-Fractionation factors were determined for each data scan of each primary standard spot. For a particular isotopic ratio (for example, ${ }^{206} \mathrm{~Pb} /{ }^{238} \mathrm{U}$ ), the fractionation factor as used here equals the accepted isotopic ratio divided by the measured ratio. A two-dimensional grid (spot number, scan 
number) of fractionation factors for each isotopic ratio was constructed for the session as a whole by fitting a series of $4^{\text {th }}$-order polynomials (excluding outliers). Under the operating conditions of the LA-ICP-MS sessions in this study, fractionation factors were found to vary strongly with scan number, decreasing with increasing scan number (presumably due to increasing ablation pit depth and the effect this had on fractionation [for example, Paton and others, 2010]).

Fractionation factors were calculated using isotopic values based on the sum of fitted Gaussians. Ages, including when the standards were treated as unknowns, were calculated using raw isotopic signal values (excluding outliers) to avoid any bias due to artifacts of the fitting of the sum of Gaussians.

Fractionation Factor Adjustment for Integrated $\alpha$-damage - Zircon is widely known to accumulate $\alpha$ radiation damage (Zhang and others, 2009). It is assumed here that increased $\alpha$-damage in a zircon leads to a decrease in the hardness of the zircon; this in turn leads to a faster rate of laser penetration into the zircon during ablation leading to shift in isotopic fractionation. Ages calculated for the primary, secondary, and tertiary zircon standards, when those standards were treated as unknowns, were used to construct a fractionation factor correction curve (exponential form). Much previous work has attempted to understand the chemical basis for why some standards work better with some zircons. The notion of matrix-matched standard and unknown zircons has been proposed largely on the basis of trace element chemistry (Black and others, 2004). Here, time and crystallographic damage, parameters invisible to instruments used to characterize trace element chemistry, were introduced and applied in conjunction with $U$ and Th chemistry.

Common Pb Correction-Common $\mathrm{Pb}$ was subtracted out using the Stacey and Kramers (1975) common $\mathrm{Pb}$ model for Earth. Ages and common $\mathrm{Pb}$ ratio were determined iteratively using a pre-set, sessionwide minimum common $\mathrm{Pb}$ age value (default for each session was the age of the oldest age standard which for both apatite and zircon was 1,099 Ma FC-1 and/or FC-5z).

Preferred Age-Uranium decay constants and the ${ }^{238} \mathrm{U} /{ }^{235} \mathrm{U}$ isotopic ratio reported in Steiger and Jäger (1977) were used in this study. ${ }^{207} \mathrm{~Pb} /{ }^{235} \mathrm{U}_{\mathrm{c}}\left({ }^{235} \mathrm{U}_{\mathrm{c}}=137.88^{238} \mathrm{U}\right),{ }^{206} \mathrm{~Pb} /{ }^{238} \mathrm{U}$, and ${ }^{207} \mathrm{~Pb} /{ }^{206} \mathrm{~Pb}$ ages were calculated for each data scan and checked for concordance; concordance here was defined as overlap of all three ages at the $1 \sigma$ level (the use of $2 \sigma$ level was found to skew the results to include scans with significant common $\mathrm{Pb}$ ). The background-corrected isotopic sums of each isotope were calculated for all concordant scans. The precision of each isotopic ratio was calculated by using the background and signal errors for both isotopes. The fractionation factor for each data scan, corrected for the effect of accumulated $\alpha$-damage, was weighted according to the ${ }^{238} \mathrm{U}$ or ${ }^{232} \mathrm{Th}$ signal value for that data scan; an overall weighted mean fractionation factor for all concordant data scans was used for final age calculation.

If the number of concordant data scans for a spot was greater than zero, then either the ${ }^{206 \mathrm{~Pb} / 238} \mathrm{U}$ or ${ }^{207} \mathrm{~Pb} /{ }^{206} \mathrm{~Pb}$ age was chosen as the preferred age, whichever exhibited the lower relative error. If zero concordant data scans were observed, then the common $\mathrm{Pb}$-corrected age based on isotopic sums of all acceptable scans was chosen as the preferred age. Common $\mathrm{Pb}$ was subtracted out using the Stacey and Kramers (1975) common $\mathrm{Pb}$ model for Earth. Ages and common $\mathrm{Pb}$ ratio were determined iteratively using a pre-set, session- 
wide minimum common $\mathrm{Pb}$ age value (default for each session was the age of the oldest age standard which for both Ap and Zrn was 1,099 Ma FC-1 and/or FC-5z).

Data from all spot analyses are shown in the detailed tables that accompany this report. In addition to the reported "preferred age" defined above (that is, either ${ }^{206} \mathrm{~Pb} /{ }^{238} \mathrm{U}$ age, ${ }^{207} \mathrm{~Pb} /{ }^{206} \mathrm{~Pb}$ age, or common $\mathrm{Pb}$-corrected age), we also calculated the concordia age (including decay constant uncertainties) for each grain analyzed. The concordia age makes optimum use of both decay schemes and obviates the need to choose an arbitrary age threshold for selecting ${ }^{206} \mathrm{~Pb} /{ }^{238} \mathrm{U}$ or ${ }^{207} \mathrm{~Pb} /{ }^{206} \mathrm{~Pb}$ age as the "preferred age" for an individual grain (Ludwig, 2012; Nemchin and Cawood, 2005). Additionally, the concordia age calculation gives probability of concordance (POC) for each analysis, which provides a useful means of assessing concordance for all grains regardless of age. After calculating the concordia age and associated statistics for each analysis, we screened the data for uncertainty and POC. Analyses with greater than 10 percent age uncertainty (at 1 sigma) were excluded or "filtered" from plots and statistical treatments. Grains with $\mathrm{POC}<0.1$ were also excluded unless the grain was older than $1,000 \mathrm{Ma}$ and had a calculated concordance (comparison of ${ }^{206} \mathrm{~Pb} /{ }^{238} \mathrm{~Pb}$ and ${ }^{207} \mathrm{~Pb} /{ }^{206} \mathrm{~Pb}$ ages) between 80 percent and 105 percent. Data that were filtered are included in the detailed data tables but are labeled as "filtered."

For metaigneous and igneous samples containing complex age distributions, grains contributing to the youngest "main" population of a sample (that is, those that are most likely contemporaneous with the crystallization of the host rock) are distinguished from "inherited" grains that are interpreted to represent xenocrysts from an older igneous or metamorphic zircon-forming event. Calculated weighted-mean ages and associated uncertainty $(2 \sigma)$ for each sample were determined using Isoplot 4.15 (Ludwig, 2012) and are shown in table 2 and the summary table. The summary table shows only the preferred age calculated for the "main" population. Representative "main" or "inheritance" values in table 2 are only shown for populations with $\geq 2$ grains. Grains that were excluded from calculated ages because of interpreted inheritance or lead loss are shown with blue bars in the figures below and are labeled as "excluded" in the detailed data tables.

For metasedimentary samples, detrital zircon age populations were calculated using the AgePick macro for Microsoft Excel (Gehrels, 2009), and results for those samples are shown in the inset tables.

\section{SAMPLE DESCRIPTIONS}

The following sample descriptions are based on field notes and thin-section petrography.

\section{Igneous rocks}

\section{WCW149-Quartz-feldsparporphyrydike east of Birch Lake}

Quartz-feldspar porphyry; pale, tan or pink, 0.05 to $5.0 \mathrm{~mm}$; Mineralogy: 10 percent quartz phenocrysts 0.5-5 mm, euhedral to subhedral, many embayed; 10 percent potassium feldspar phenocrysts 1-3 mm, weakly sericitized, some overgrowing smaller plagioclase phenocrysts; 1 percent plagioclase phenocrysts $0.5-1 \mathrm{~mm}$, weakly sericitized; 1 percent biotite phenocryst pseudomorphs, $0.5-2 \mathrm{~mm}$, completely replaced by mixture of white mica and opaque minerals; 78 percent groundmass, 25-50 micron intergrown quartz-feldspar-white mica. Rock is weakly to moderately altered to sericite. Sampled from float. 


\section{AW002 - Quartz-feldspar porphyry dike, Democrat prospect}

Altered quartz-felspar porphyry; pale gray to cream colored with an iron-oxide stain. Mineralogy: 3 percent euhedral feldspar phenocrysts $2-9 \mathrm{~mm}$, partially sericitized; 3 percent euhedral quartz phenocrysts 2$5 \mathrm{~mm}$; 1 percent sericite and opaque pseudomorphs, likely after 1-2 mm diameter biotite phenocrysts. The balance of the rock is aphanitic, pale gray groundmass composed of 50- to 100-micron sized feldspar, quartz, and sericite. The rock is altered to a sericitic assemblage; vugs and veins are filled with quartz, often large and euhedral. The sample was collected from outcrop; it is partially weathered and stained by limonite and scorodite.

\section{ET587 - Birch Lake pluton}

Granite; light pink-tan, porphyritic, medium-grained. Mineralogy: 30 percent potassium feldspar, including subhedral phenocrysts up to $20 \mathrm{~mm}$; 35 percent plagioclase, subhedral, moderately sericitized; 30 percent quartz, interstitial; 4 percent biotite, fresh to pervasively chloritized, 1 percent hornblende, $1 \mathrm{~mm}$ grains. Larger hornblende grains in some cases have a core of biotite or are rimmed and intergrown with biotite. Mafic enclaves 5-30 cm in diameter make up 0.1 percent of the exposure. Sample from outcrop, partially weathered.

\section{ET580 - Gold Run pluton}

Granite; tan, medium-grained, porphyritic. Mineralogy: 1 percent potassium feldspar phenocrysts up to $30 \mathrm{~mm} ; 65$ percent subhedral intergrown potassium and plagioclase feldspar; 30 percent quartz, interstitial, weakly strained; 4 percent biotite, $1 \mathrm{~mm}$, partially chloritized along foliation planes; 1 percent hornblende, 0.5 $5 \mathrm{~mm}$, individual grains and aggregates, locally intergrown with biotite at the grain margins; trace zircon hosted within biotite and hornblende. Texture and chemical composition are similar to the Birch Lake pluton. Sampled from float, partially weathered.

\section{RN565 - Phaneritic granodiorite, Democrat prospect}

Granodiorite; dirty gray-green color in hand sample; seriate, with grain size ranging from 0.5 to $5 \mathrm{~mm}$. Mineralogy: 40 percent plagioclase, euhedral to subhedral grains about $1 \mathrm{~mm}$ in diameter; 25 percent quartz, partly recrystallized, showing undulose extinction and sinuous grain boundaries; 20 percent potassium feldspar, including oikocrysts to $5 \mathrm{~mm}$ that enclose plagioclase grains; 10 percent biotite, $0.5-1 \mathrm{~mm}$ grains, almost completely replaced by chlorite; 1 percent possible hornblende, now completely replaced by chlorite. Feldspars are only weakly altered to sericite. The sample is cut by two thin $(0.2-1 \mathrm{~mm})$ cataclastic bands of crushed quartz and feldspar. Sampled from subcrop; trace weathering.

\section{Metaigneous rocks}

\section{ET040 - Augen orthogneiss}

Augen orthogneiss; light gray, gneissic; grain size: 0.5 to $8.0 \mathrm{~mm}$; Mineralogy: 3 percent potassium feldspar augen 3-10 mm; 57 percent feldspar, dominated by potassium feldspar, 0.1-0.5 mm; 35 percent 
quartz, $0.2 \mathrm{~mm}, 5$ percent biotite, $0.2 \mathrm{~mm}$, not visible chlorite alteration. Myrmekitic intergrowths of feldspar and quartz are common. Sampled from subcrop.

\section{Detrital zircons from metasedimentary rocks}

18AW021-Semischist

Semischist (metamorphosed siliciclastic sedimentary rock). Texture: schistose to gneissic with sub-1 mm layers, locally preserving two fabrics, the earlier of which is largely transposed. Mineralogy: 80 percent quartz, including relict individual and polycrystalline detrital grains $0.5-2 \mathrm{~mm}$, plus granoblastic groundmass around $0.1 \mathrm{~mm}$ intergrown with micas; 14 percent white mica, $0.1-0.2 \mathrm{~mm}$, defining schistosity in anastomosing bands and also suggesting an earlier, transposed fabric; chlorite, 5 percent, $0.1 \mathrm{~mm}$, similar habit to white mica. Minor relict biotite appears to be preserved within chlorite, suggesting chlorite is the retrograde product of biotite. 1 percent plagioclase grains, 0.1-0.2 mm, with polysynthetic twinning. Weathering: trace; sampled from outcrop.

\section{TJN372 — Garnet-biotite-muscovite schist}

Garnet-biotite-muscovite schist. Mineralogy: 80 percent muscovite, 1-2 mm, strongly sericitized in patches; 10 percent quartz, as lenses with $0.1-0.2 \mathrm{~mm}$ granoblastic grains; 5 percent biotite, $1-2 \mathrm{~mm}$, intergrown with muscovite; 3 percent plagioclase, $1-3 \mathrm{~mm}$, foliation-parallel or as porphyroclasts; 2 percent garnet, 1-3 mm porphyroclasts, partly retrograded to muscovite and biotite; possible andalusite, less than 1 percent. Sampled from outcrop.

\section{RESULTS}

A summary of all interpreted $\mathrm{U}-\mathrm{Pb}$ ages is included in table 2, with uncertainty for all ages and isotope ratios reported at the $2 \sigma$ level. As outlined above, a concordance filter was used to eliminate grains that were either heterogeneous or experienced $\mathrm{Pb}$ loss after formation. Filtered grains were not included in the final interpreted ages reported below. 
Table 2. Summary of preferred $\left({ }^{238} \mathrm{U} / 206 \mathrm{~Pb}\right)$ weighted-average igneous crystallization ages. Sample coordinates are given in the WGS84 datum. No preferred age is given for detrital zircon samples.

\begin{tabular}{|c|c|c|c|c|c|c|}
\hline Sample & $\begin{array}{l}\text { Latitude/ } \\
\text { Longitude }\end{array}$ & Lithology & $\begin{array}{l}\text { Preferred } \\
\text { age and } \\
2 \sigma \text { error } \\
(\mathrm{Ma})\end{array}$ & MSWD & $\begin{array}{l}\text { Spots } \\
\text { used } / \\
\text { Total } \\
\text { spots }\end{array}$ & Interpretation notes \\
\hline 18WCW149 & $\begin{array}{l}64.40725 / \\
-146.70035\end{array}$ & $\begin{array}{l}\text { Quartz-feldspar } \\
\text { porphyry }\end{array}$ & $56.8 \pm 0.9$ & 0.61 & $16 / 17$ & \\
\hline 18AW002 & $\begin{array}{l}64.33556 / \\
-146.35762\end{array}$ & $\begin{array}{l}\text { Quartz-feldspar } \\
\text { porphyry } \\
\text { (Democrat prospect) }\end{array}$ & $92.0 \pm 0.7$ & 0.65 & $32 / 35$ & \\
\hline $18 \mathrm{ET} 587$ & $\begin{array}{l}64.31633 / \\
-146.55405\end{array}$ & $\begin{array}{l}\text { Granite } \\
\text { (Birch Lake pluton) }\end{array}$ & $92.4 \pm 0.6$ & 1.18 & $34 / 35$ & \\
\hline 18ET580 & $\begin{array}{l}64.40366 / \\
-146.39503\end{array}$ & $\begin{array}{l}\text { Granite } \\
\text { (Gold Run pluton) }\end{array}$ & $93.7 \pm 0.7$ & 1.3 & $32 / 35$ & \\
\hline 18RN565 & $\begin{array}{l}64.34356 / \\
-146.39545\end{array}$ & $\begin{array}{l}\text { Granodiorite } \\
\text { (Democrat prospect) }\end{array}$ & $110.7 \pm 1.3$ & 1.3 & $26 / 32$ & $\begin{array}{l}\text { A separate, older population } \\
\text { ( } 6 \text { grains, weighted average } \\
\text { age of } 122.7 \pm 2.6 \mathrm{Ma} \text { ) may } \\
\text { represent inheritance from an } \\
\text { earlier magmatic cycle. }\end{array}$ \\
\hline $18 \mathrm{ETO} 40$ & $\begin{array}{l}64.34957 / \\
-146.57290\end{array}$ & Augen orthogneiss & $364.5 \pm 6.0$ & 1.9 & $13 / 40$ & $\begin{array}{l}\text { Devonian protolith, younger } \\
\text { metamorphism and/or Pb- } \\
\text { loss }\end{array}$ \\
\hline 18AW021 & $\begin{array}{l}64.29067 / \\
-146.37923\end{array}$ & $\begin{array}{l}\text { Semischist } \\
\text { (meta-siliciclastic) }\end{array}$ & & & $\begin{array}{c}105 / \\
110\end{array}$ & $\begin{array}{c}\text { Detrital, major age } \\
\text { populations at ca. } 2.6 \text { and } 1.8 \\
\text { Ga }\end{array}$ \\
\hline 18TJN372 & $\begin{array}{l}64.42624 / \\
-146.65257\end{array}$ & $\begin{array}{l}\text { Garnet-biotite- } \\
\text { muscovite schist }\end{array}$ & & & $22 / 31$ & Detrital; low yield \\
\hline
\end{tabular}




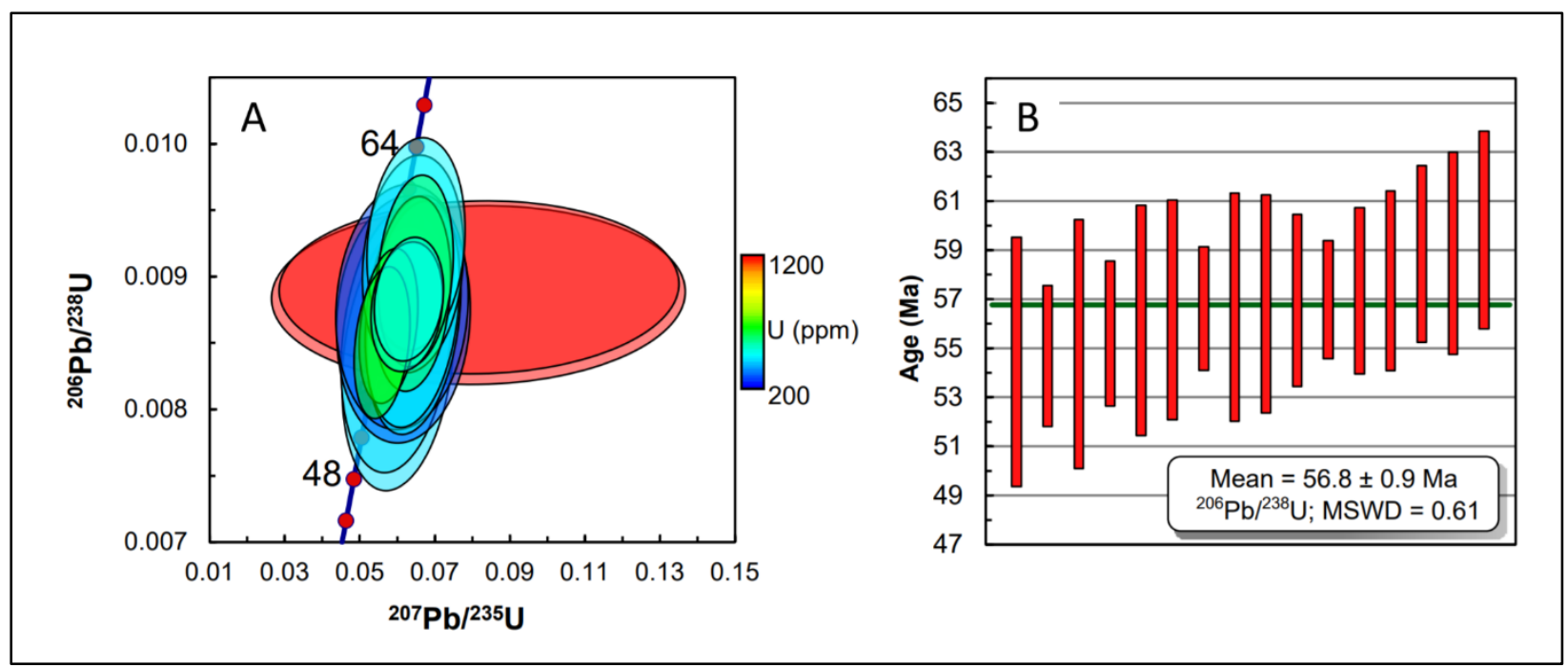

Figure 2.U-Pb plots for sample 18WCW149: A. concordia diagram, with ovals colored by U concentration; B. Plot of ${ }^{206} \mathrm{~Pb} / 238 \mathrm{U}$ ages with weighted average of accepted ages. One grain failed to meet the concordance criteria and is excluded from the age calculation. Ovals $(\mathbf{A})$ and bars $(\mathbf{B})$ indicate uncertainty at the 2-sigma level.
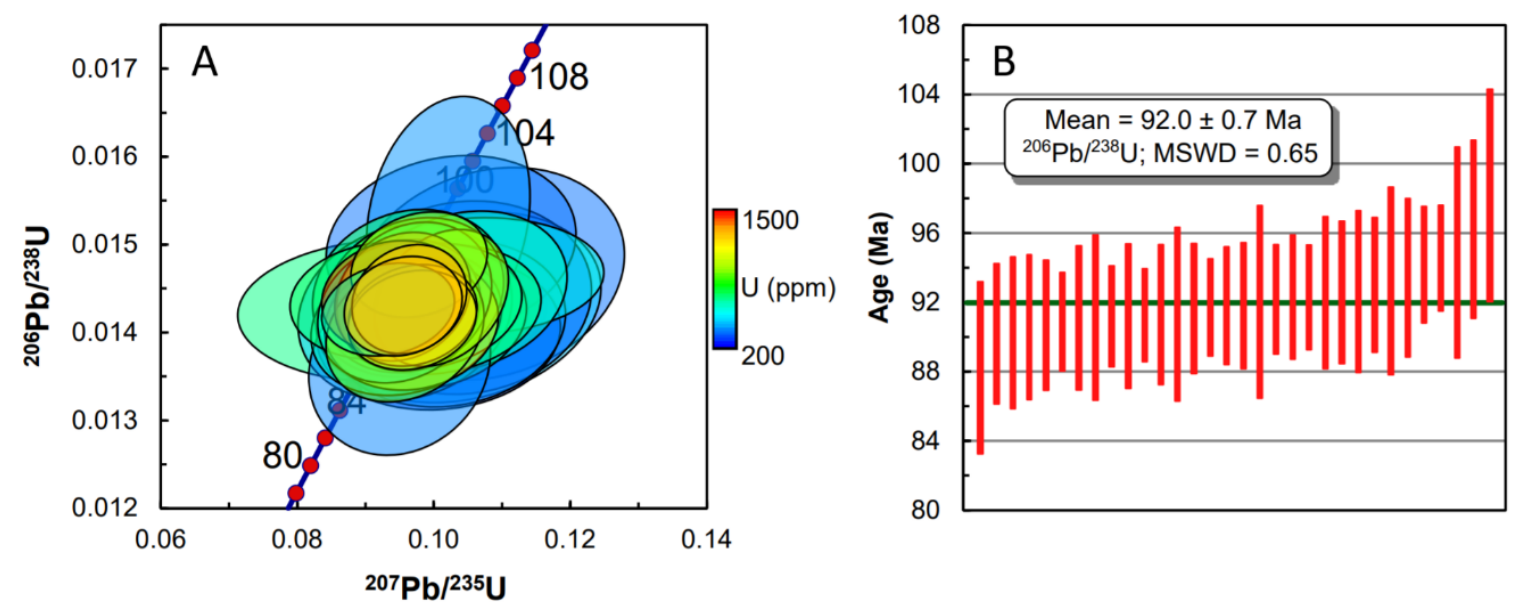

Figure 3. U-Pb plots for sample 18AW002: A. concordia diagram, with ovals colored by U concentration; B. Plot of ${ }^{206} \mathrm{~Pb} /{ }^{238} \mathrm{U}$ ages with weighted average of accepted ages. Three grains failed to meet the concordance criteria and were excluded from the age calculation. Ovals (A) and bars (B) indicate uncertainty at the 2-sigma level. 


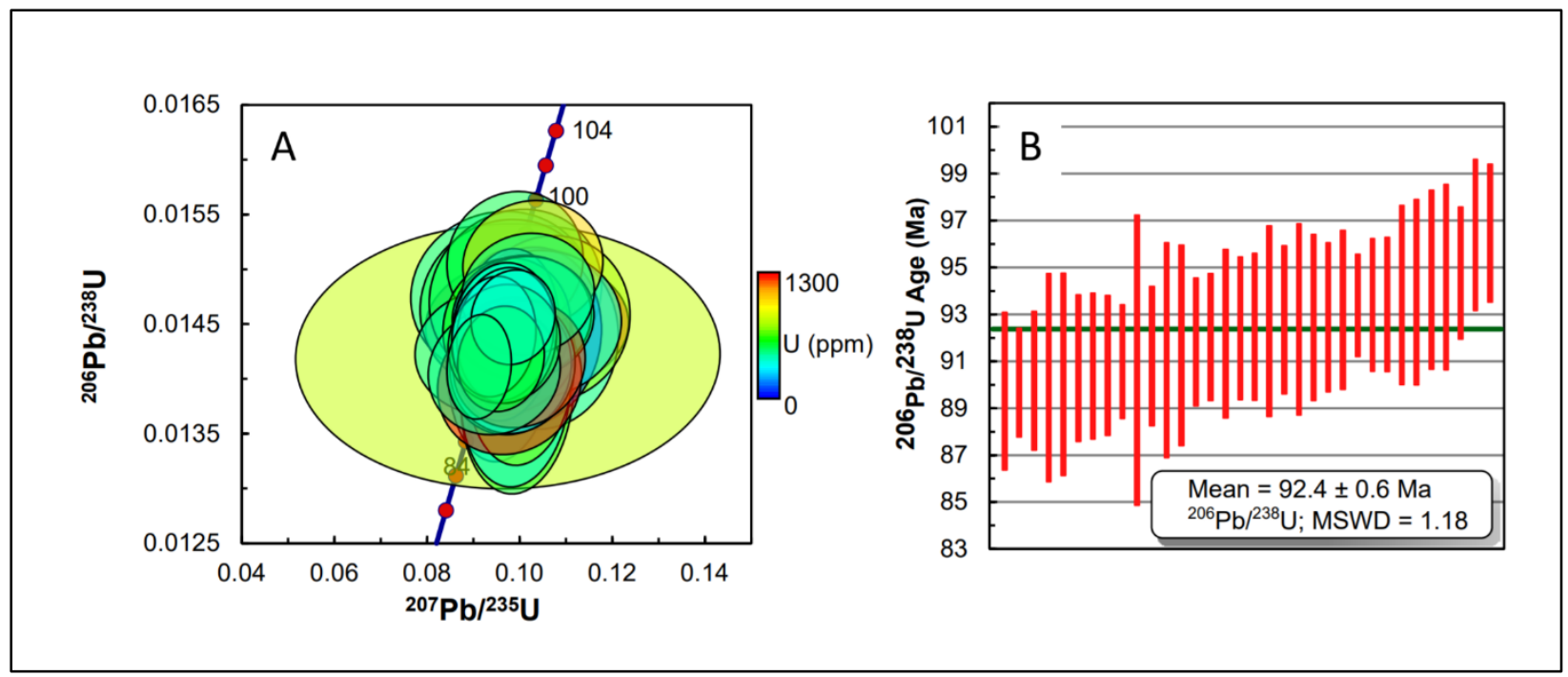

Figure 4. U-Pb plots for sample 18ET587: A. concordia diagram, with ovals colored by U concentration; B. Plot of ${ }^{206} \mathrm{~Pb} /{ }^{238} \mathrm{U}$ ages with weighted average of accepted ages. One grain failed to meet the concordance criteria and is excluded from the age calculation. Ovals ( $\mathbf{A})$ and bars (B) indicate uncertainty at the 2-sigma level.

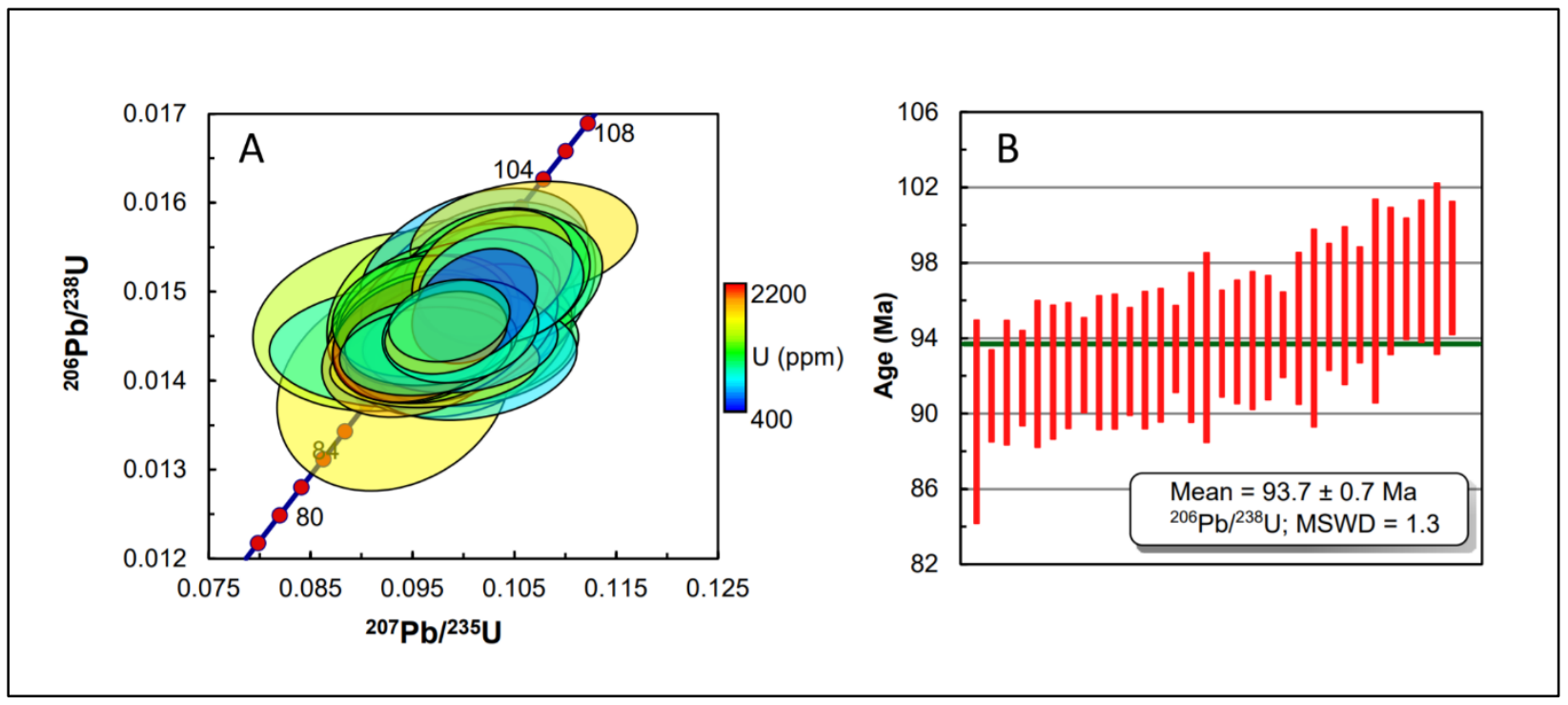

Figure 5. U-Pb plots for sample 18ET580: A. concordia diagram, with ovals colored by U concentration; $\mathrm{B}$. Plot of ${ }^{206} \mathrm{~Pb} /{ }^{238} \mathrm{U}$ ages with weighted average of accepted ages. Three grains failed to meet the concordance criteria and are excluded from the age calculation. Ovals (A) and bars (B) indicate uncertainty at the 2-sigma level. 


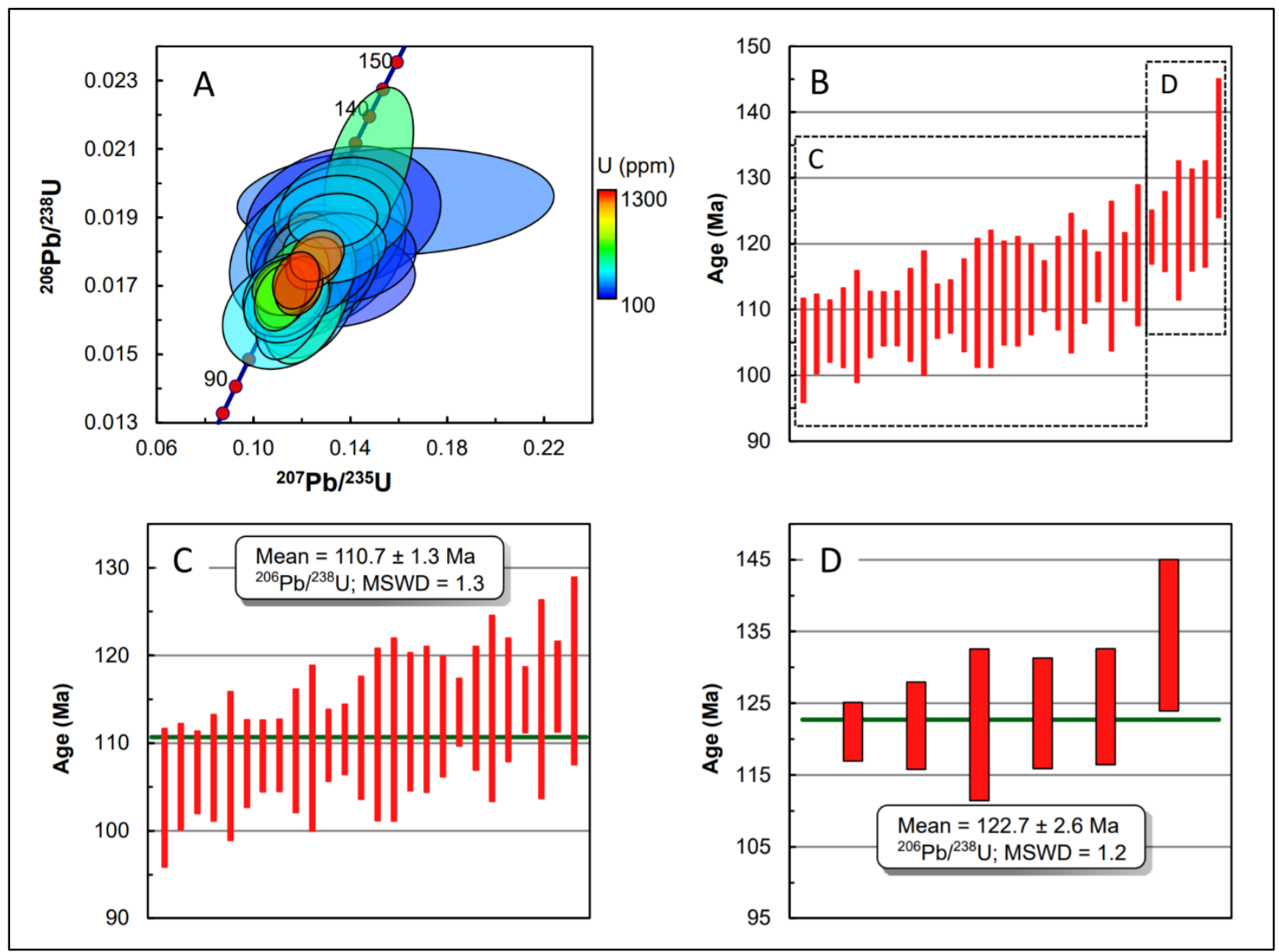

Figure 6. U-Pb plots for sample 18RN565: A. concordia diagram, with ovals colored by U concentration. B. Plot of ${ }^{206} \mathrm{~Pb} /{ }^{38} \mathrm{U}$ ages for all grains, with dashed boxes outlining two interpreted subpopulations. C. Plot of ${ }^{206} \mathrm{~Pb} /{ }^{238} \mathrm{U}$ ages and weighted average age calculation for the younger subpopulation of 26 analyses. D. Plot of ${ }^{206} \mathrm{~Pb} /{ }^{238} \mathrm{U}$ ages and weighted average age calculation for an older subpopulation of 6 analyses. Three grains failed to meet the concordance criteria and are excluded from the age calculations. Ovals (A) and bars (B-D) indicate uncertainty at the 2-sigma level. 

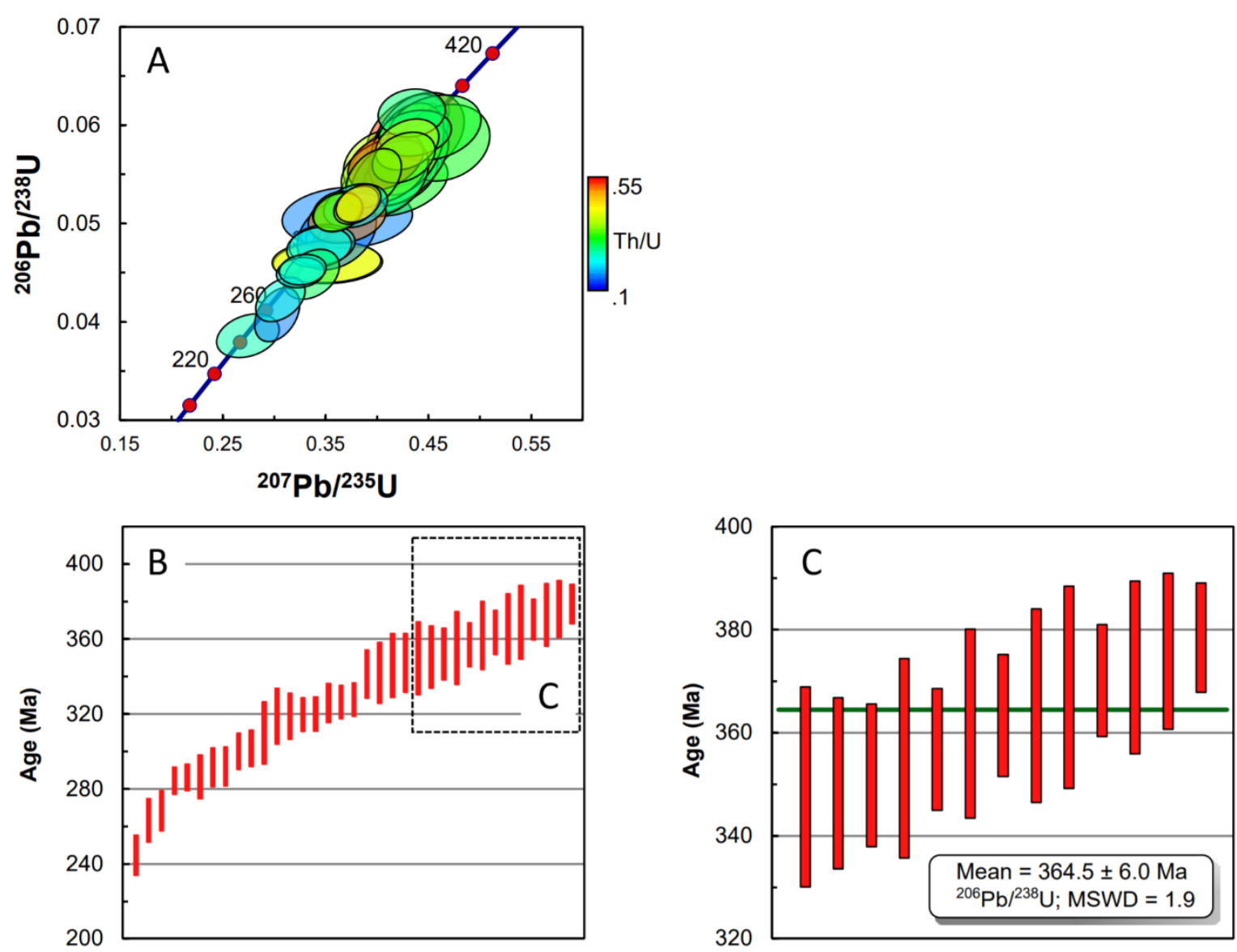

Figure 7. U-Pb plots for sample 18ET040: A. concordia diagram, with ovals colored by Th/U ratio. B. Plot of ${ }^{206} \mathrm{~Pb} / 238 \mathrm{U}$ ages for all grains, with dashed boxes outlining an interpreted subpopulation. C. Plot of ${ }^{206} \mathrm{~Pb} /{ }^{338} \mathrm{U}$ ages and weighted average age calculation for the subpopulation of 13 analyses. Three grains failed to meet the concordance criteria and are excluded from the age calculations. Ovals (A) and bars (B, C) indicate uncertainty at the 2-sigma level. 

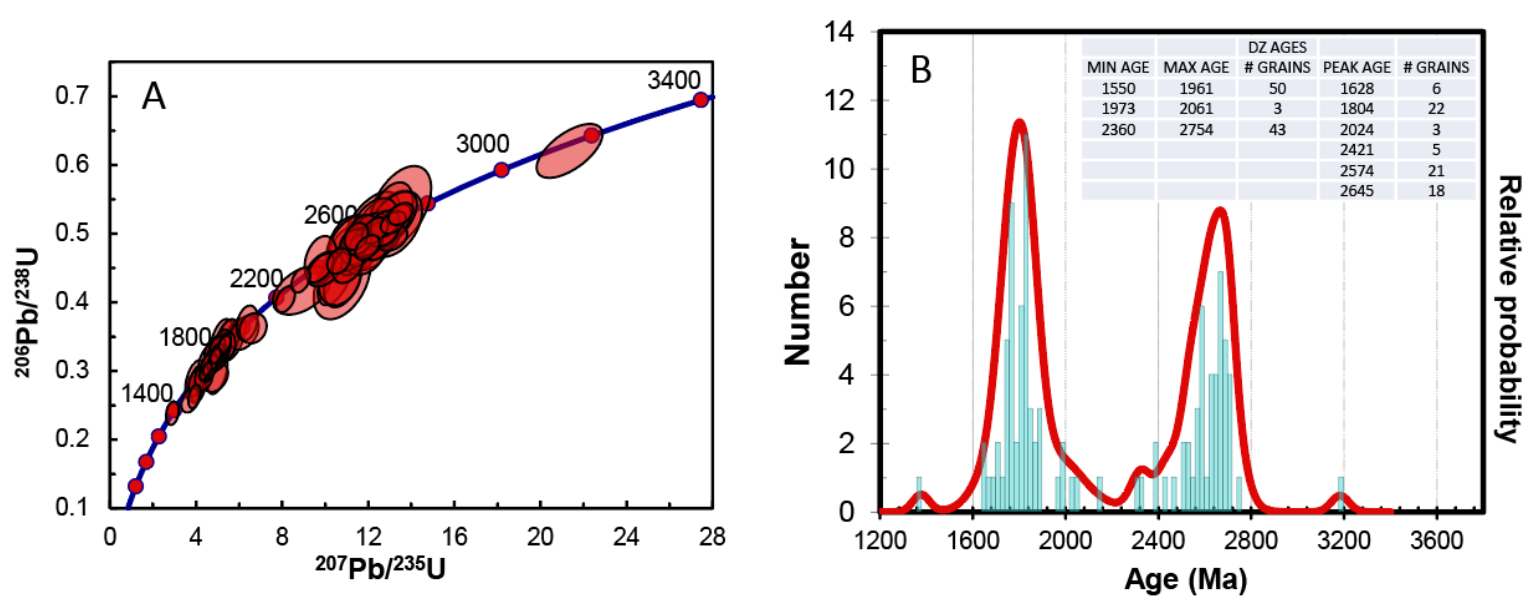

Figure 8. U-Pb plots for sample 18AW021. A. concordia diagram. B. Probability density plot, with inset table showing detrital zircon age populations calculated using the AgePick Microsoft Excel macro of Gehrels (2009). Five of 110 grains failed to meet the concordance criteria and are excluded from B. Ovals in A indicate uncertainty at the 2-sigma level.

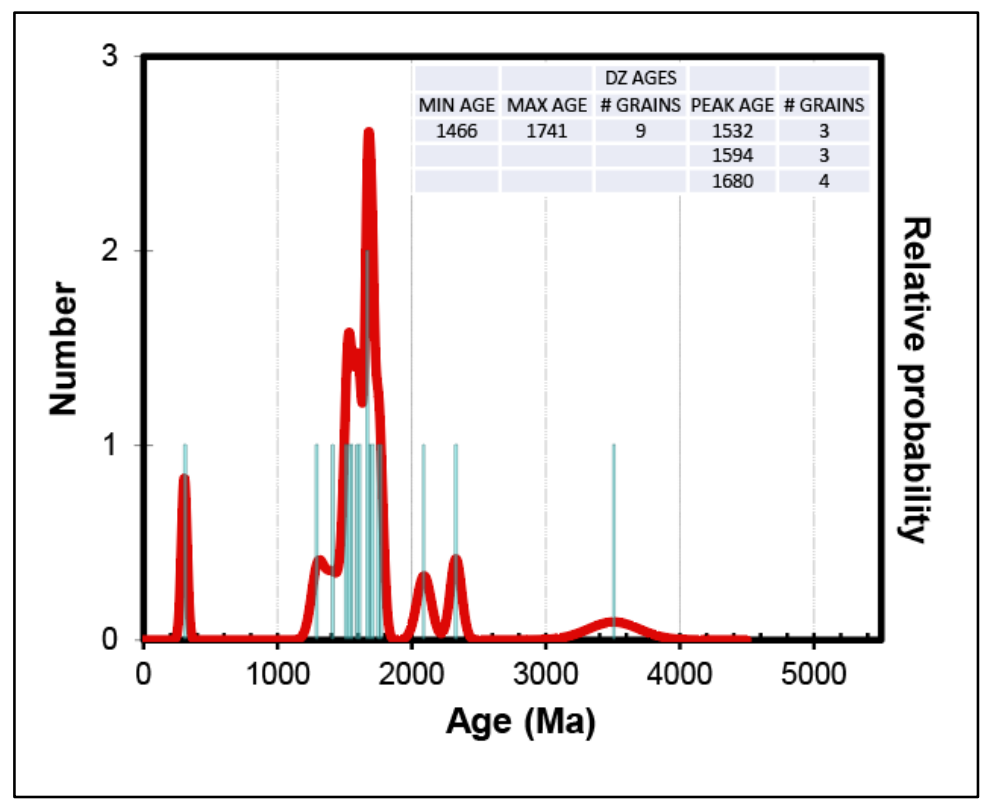

Figure 9. Probability density plot for sample 18TJN372, with inset table showing detrital zircon age populations calculated using the AgePick Microsoft Excel macro of Gehrels (2009). Nine of 31 grains analyzed failed to meet the concordance criteria and are not plotted. 


\section{ACKNOWLEDGMENTS}

We gratefully acknowledge James V. Jones III for his assistance with the age interpretations and figures. The 2018 Richardson geologic mapping project was funded by the State of Alaska.

\section{REFERENCES}

Black, L.P., Kamo, S.L., Allen, C.M., Davis, D.W., Aleinikoff, J.N., Valley, J.W., Mundil, Roland., Campbell, I.H., Korsch, RJ., Williams, I.S., and Foudoulis, Chris, 2004, Improved ${ }^{206} \mathrm{~Pb} /{ }^{238} \mathrm{U}$ microprobe geochronology by the monitoring of a trace-element-related matrix effect; SHRIMP, ID-TIMS, ELAICP-MS and oxygen isotope documentation for a series of zircon standards: Chemical Geology, v. 205, n. 1-2, p. 115-140.

Chang, Zhaoshan, Vervoort, J.D., McClelland, W.C., and Knaack, Charles, 2006, U-Pb dating of zircon by LA-ICP-MS: Geochemistry, Geophysics, Geosystems, v. 7, n. 5, 14 p.

Donelick, R.A., O'Sullivan, P.B., and Ketcham, R.A., 2005, Apatite fission-track analysis: Reviews in Mineralogy and Geochemistry, v. 58, n. January 2005, p. 49-94.

Dusel-Bacon, Cynthia, Holm-Denoma, C.S., Jones, J.V. III, Aleinikoff, J.N., and Mortensen, J.K., 2017, Detrital zircon geochronology of quartzose metasedimentary rocks from parautochthonous North America, east-central Alaska: Lithosphere, v. 9, n. 6, p. 927-952; GSA Data Repository Item 2017332. https://doi.org/10.1130/L672.1

Dusel-Bacon, Cynthia, Hopkins, M.J., Mortensen, J.K., Dashevsky, S.S., Bressler, J.R, and Day, W.C., 2006, Paleozoic tectonic and metallogenic evolution of the pericratonic rocks of east-central Alaska and adjacent Yukon: in Colpron, Maurice, and Nelson J.L., eds., Paleozoic Evolution and Metallogeny of Pericratonic Terranes at the Ancient Pacific Margin of North America, Canadian and Alaskan Cordillera: Geological Association of Canada Special Paper 45, p. 25-74.

Gehrels, G.E., Valencia, V.A., and Ruiz, Joaquin, 2008, Enhanced precision, accuracy, efficiency, and spatial resolution of $\mathrm{U}-\mathrm{Pb}$ ages by laser ablation-multicollector-inductively coupled plasma-mass spectrometry: Geochemistry, Geophysics, Geosystems, v. 9, n. 3, p. 1-13.

Gehrels, G., 2009, Age Pick program, Excel 2003 macro. https://rive.google.com/file/d/0B9ezu34P5h8eNWRkMGZkNTgtZDdhOC00OGZkLTkxNjUtYzY5 M2UzYjU1ZmVi/view?hl=en US.

Kuiper, K.F., Deino, Alan, Hilgen, F.J., Krijgsman, Wout, Renne, P.R., and Wijbrans, J.R, 2008, Synchronizing rock clocks of earth history: Science, v. 320, n. 5,875, p. 500-504.

Lanphere, M.A., and Baadsgaard, Halfdan., 2001, Precise K-Ar, ${ }^{40} \mathrm{Ar} /{ }^{39} \mathrm{Ar}$, Rb-Sr and U-Pb mineral ages from the 27.5 Ma Fish Canyon Tuff reference standard: Chemical Geology, v. 175, p. 653-671.

Ludwig, K.R., 2012, User's Manual for Isoplot 3.75, A Geochronological Toolkit for Microsoft Excel: Berkeley Geochronology Centre Special Publication no. 5 (rev. January 30, 2012), 75 p., Berkeley, CA, USA.

Nemchin, A.A., and Cawood, P.A., 2005, Discordance of the U-Pb system in detrital zircons: Implication for provenance studies of sedimentary rocks: Sedimentary Geology, v. 182, p. 143-162. https://doi.org/10.1016/j.sedgeo.2005.07.011 
Paces, J.B., and Miller, J.D., 1993, Precise U-Pb ages of Duluth Complex and related mafic intrusions, northeastern Minnesota: Geochronological insights to physical, petrogenic, paleomagnetic, and tectonomagmatic processes associated with the $1.1 \mathrm{Ga}$ Midcontinent Rift System: Journal of Geophysical Research, v. 98, n. B8, p. 13,997-14,013.

Paton, Chad, Woodhead, J.D., Hellstrom, J.C., Hergt, J.M., Greig, Alan, and Maas, Roland, 2010, Improved laser ablation $\mathrm{U}-\mathrm{Pb}$ zircon geochronology through robust downhole fractionation correction: Geochemistry, Geophysics, Geosystems, v. 11, n. 3, 36 p.

Renne, P.R., Swisher, C.C., Deino, A.L., Karner, D.B., Owens, T.L., and DePaolo, D.J., 1998, No Intercalibration of standards, absolute ages and uncertainties in ${ }^{40} \mathrm{Ar} /{ }^{39} \mathrm{Ar}$ dating: Chemical Geology, v. 45, p. $117-152$.

Singh, R.B., Freeman, C.J., and Cronk, W.J., 2017, NI 43-101 technical report for the Richardson gold property, Richardson Mining District, Alaska: NI 43-101 technical report prepared for Northern Empire Resources Corp. uploaded to sedar.com January 5, 2017.

Stacey, J.S., and Kramers, J.D., 1975, Approximation of terrestrial lead isotope evolution by a two-stage model: Earth and Planetary Science Letters, v. 26, n. 2, p. 207-221.

Steiger, R.H., and Jäger, E., 1977, Subcommission on geochronology: Convention on the use of decay constants in geo- and cosmochronology: Earth and Planetary Science Letters, v. 36, n. 3, p. 359-362.

Zhang, Ming, Ewing, R.C., Boatner, L.A., Salje, E.K.H., Weber, W.J., Daniel, Philippe, Zhang, Yanwen, and Farnan, Ian, 2009, Pb+ irradiation of synthetic zircon (ZrSi04): Infrared spectroscopic investigationReply: American Mineralogist, v. 94, n. 5-6, p. 856-858. 